\title{
Singapore
}

\section{Information lockdown, business as usual}

\author{
Garry Rodan
}

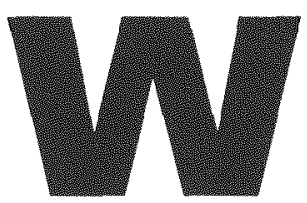

ithin the neat, high rise towers of Singapore's economic success sit hundreds of thousands of personal computers, the gateways into the global information age in one of the world's most technologically sophisticated societies. Yet, behind the gentle whirring of the browsers and the email, lie the gatekeepers of the global information age, the officials of the Singapore government. Earlier this year, that government wandered into almost half of the 400,000 computers of Internet users, without their knowledge, in what was explained as a sweep for computer viruses. Five years earlier a similar search of private and business computer files was attributed to a crack down on pornography. By the year 2000, through the government-contracted Singapore One Cable Network, all 750,000 households on the island will be connected to a comprehensive national computer web, including broadband coaxial and optical fibre networks, linking homes to businesses, schools, government departments and libraries. In the world's first fully interactive nation state, all citizens will have the facility to carry out commercial transactions, access interactive services and communicate with each other via the Internet. And the Singapore government will have cyber access to every home on the island.

\section{Confounding the theorists}

For decades Singapore has fascinated political observers with its apparently contradictory mix of free market capitalism and political controls-Asia's big brother or big father society was making it in the freewheeling international marketplace. Founding Prime Minister, Lee Kuan Yew, contributed significantly to the regional debate of the mid 1980s 
to the late 1990s over Asian values. Lee Kuan Yew argued that in Singapore the curtailing of western-style freedoms such as freedom of speech and freedom of the press met a 'higher' goal of social stability in turn paving the way for rapid economic development. Thus, a government had the moral right to curtail an individual's freedoms in exchange for economic rights, the right to be richer and more comfortable in Singapore's carefully planned high rise residential developments. Critics contended that Singapore worked only because of its size-Singapore was confounding conventional political theory because it was small enough to manage, more a moderate sized modern city than a nation.

But, as Asia enters the new millennium Singapore seems poised to confound theorists yet again, this time by defying the explosive forces for change unleashed by rapid developments in information technology. While other authoritarian governments are chasing dissidents flashing ideas and information across the Internet and attempting to build electronic firewalls when the fire is already burning, the Singapore government is building the entire system itself. While there is considerable evidence to demonstrate that new information technology has directly contributed to the collapse of authoritarian regimes, Singapore is applying sophisticated strategies to control both the local and foreign media. Ironically, Singapore is poised to become the world's second-most dominant information society, after the United States, by the year 2000 (Chellam 1999), yet there are no signs of media controls being loosened. What is lost to the local population is not just freedom of speech to a political end, but the right to scrutinise the economy, including the investments worth $\mathrm{S} \$ 100$ billion dollars made by the government using tax payers' money (Ong 1999).

Singapore's impressive economic development over recent decades has been accompanied by a tight regime of controls over all media, including the Internet. While the East Asian economic crisis, which began in 1997, has fuelled forces for political change elsewhere, the comparatively moderate impact of the crisis on Singapore has strengthened the authorities' belief that existing social and political systems are essential to the country's economic well-being.

This is not to say there are no challenges ahead for Singapore's leaders. In particular, the ambitious new goal of turning the city-state into an 
international finance centre could entail functional, if not political, pressure for a freer media. Is it any coincidence that leading international finance centres such as London, New York and Frankfurt boast free and critical media? Yet Singapore is already an important Asian media centre. Thus far, then, a flourishing volume and range of media forms and activities have been reconciled with selective and strategic control over information and critical analysis. Against this background, the capacity of authorities to respond to new challenges should not be underestimated.

Any understanding of how media operate in Singapore must be coupled with an appreciation of the political system. Uninterrupted rule by the People's Action Party (PAP) since self-government in 1959 has involved the establishment, and consolidation, of a state that systematically limits political competition. The space for critics and opponents of the PAP is highly conditional and channelled almost exclusively through the controlled electoral process. Organisations that engage in politics are expected to be specifically registered for that purpose, otherwise they risk dissolution under the Societies Act. Individuals who publicly criticise the government are challenged to join a political party and warned not to use independent social organisations as a front for a 'hidden agenda'. Thus, critical comments about amendments to the Newspaper and Printing Presses Act in 1986 by Law Society office bearers aroused official rebuke (Duthie 1986), followed by changes to the Legal Profession Act. This prohibited the Society from, inter alia, commenting on existing or proposed legislation unless the government specifically requested its views (Seow 1997). Similarly, novelist Catherine Lim's (1994) lamenting in a Sunday Times article that Goh Chok Tong's promise of a more consensual approach was not materialising sparked a series of fierce public denunciations by the Prime Minister (Chua 1994; Fernandez 1994). The concept of 'out-of-bounds' or $O B$ limits to public engagement was introduced with Lee Kuan Yew declaring '[y] ou want to move the $O B$ markers, then you come out (into politics) and persuade the electorate' ( $\mathrm{Ng} 1995)$.

This suppression of civil society deprives opposition parties of the opportunity to forge social links and to mobilise support through interest groups. The political risk of elections for the ruling party is thereby considerably reduced. 
Within this system, there is also little scope for critical media. Contests with, and challenges to, the ruling party through the media are regarded as covert political activities which should also be reserved for the electoral process. Nevertheless, the domestic media loom large in Singapore politics, being systematically harnessed to the exercise of explaining PAP policy and generating support for it. As the government and local editors admit without apology, they are partners in nation building. Local newspapers are full of bland reports on community-based activities, the pinnacle of which seems to be the annual 'Singapore Swing' dance in the city streets, as well as self-congratulatory articles on upstanding members of society. Meanwhile, editors and reporters from the international media have learnt to report cautiously on local affairs or face the consequences of costly legal cases and commercially injurious circulation limits.

In neighbouring Indonesia and Malaysia, economic and political crises in the last two years have dealt major blows to the credibility, and effectiveness, of government-controlled media. The appetite for accurate and speedy accounts of the tumultuous recent events drew domestic populations to alternative sources of information, such as Internet 'culls' of more critical reports from foreign publications bounced back into both Malaysia and Indonesia. There has been no parallel in Singapore. Nevertheless, the regional crisis has set in train an unprecedented emphasis by the World Bank, the International Monetary Fund and influential economic analysts on the importance of transparency. With international investors in mind, the Singapore government has been quick to embrace the rhetoric of transparency. This language at least gives advocates of a freer media in Singapore something to exploit. If international business in Singapore were seriously committed to a comprehensive transparency agenda, and valued the role of a free media to it, the prospects of some change might be enhanced. Thus far, there is no evidence of either.

\section{The local press remains tongue tied}

At the beginning of self-government in 1959 and well into the 1960s, Singapore boasted a wide range of independent newspapers. These provided a significant measure of scrutiny and critical examination of public policies and issues, and newspapers owned and run by families or 
individuals were relatively free from government intrusion. However, sensitivity to media reporting intensified after 1961 as the PAP set about defeating its formal political opponents, the breakaway Barisan Nasional (BS). Incrementally, a new regime was installed through a combination of pressures on media organisations and journalists. This included general harassment of journalists, some of whom were detained under the Internal Security Act (ISA), such as four senior executives of the Chinese-language daily Nanyang Siang Pau, and the closure of the English-language dailies Eastern Sun and the Herald (Seow 1998). Under the ISA, suspected subversives can be detained without trial and the relevant minister is empowered to prohibit the printing, publication, and sale, inter alia, of subversive publications (Seow 1998). But, it was structural changes to the newspaper industry which had the most profound and lasting impact.

The decisive step was a set of amendments to the Newspapers and Printing Presses Act (NPPA) in 1974. The official rationale for the changes was to 'safeguard public interest by ensuring undesirable foreign elements do not gain control of our newspapers and use them against the welfare of our society' (Hansard quoted in Seow 1998). The amendments required the compulsory divestiture of ownership shareholdings, which allowed governments to own newspapers, and forced all newspaper organisations to become public companies. It also created different classes of sharesordinary and management-with the latter carrying more votes and owned only by people approved by the Ministry of Culture (as it was then known). Subsequently, in 1977, a further amendment prevented any person from owning more than three per cent of the ordinary stock issued by a newspaper. The purpose of the amendments was to ensure that private families and individuals could no longer own newspapers and that the government could secure reliable management of the press.

In the early 1980s, the government's ability to control the local media was extended further through a major restructuring, in the guise of commercial rationalisation. This involved the establishment of a new government-initiated company, Singapore Monitor Ltd., to produce a new English-language afternoon daily to complement The Straits Times. Meanwhile, leading daily Chinese-language rivals, Nanyang Siang Pau and Sing Chew Jit Poh, were merged into a single holding company, Singapore News and Publications Ltd. (SNPL), of which the Singapore Monitor became a subsidiary. The management of SNPL was entrusted 
to senior government officials. By March 1983, Sin Chew Jit Poh and Nanyang Siang Pau had been replaced by two new dailies-Lin He Zaobao (United Morning News) and Lian He Wanbao (United Evening News). These changes meant there were now two newspaper groups, each producing a morning and afternoon daily in English or Chinese. However, the concentration of ownership and control of Singapore's press was consolidated further still when in 1984 the Straits Times group, which comprised the Straits Times Press and its sister company Times Publishing, merged with the SNPL to form Singapore Press Holdings (SPH). Capitalised at $\mathrm{S} \$ 1.4$ billion (US $\$ 660$ million), it constituted the largest industrial group in Singapore and the country's sixth largest listed company (Lent 1984).

This restructuring cemented, what was by then, a powerful capacity by government to exert control over domestic newspapers. The subsequent purchase in 1995 by SPH of Tamil Murasu made the holding company the

\section{2. ingapore media profile}

Today there are eight daily newspapers in Singapore: The Straits Times, The New Paper and The Business Times (English); Lianhe Wanbao, Shin Min Daily News and Lianhe Zaoboa (Chinese); Berita Harian (Malay); and Tamil Murasu (Tamil). All of these publications have online editions and all but The Business Times produce a Sunday edition. Daily circulation of newspapers has risen steadily from 743,334 in 1988 to $1,054,802$ by the end of 1998 . The greatest gains have been made by English-language publications, the daily circulation of which rose from 340,401 to 530,628 in the same period. By the early 1990s, this eclipsed daily circulation of Chinese-language dailies, which increased from 354,840 to 454,651 over the decade. The Straits Times is the dominant English-language newspaper, with a daily circulation in 1998 of around 396,000 and an estimated total daily readership in 1997 of 1,228,000. Lianhe Zaoboa is the Chinese-language equivalent, with daily circulation in 1998 of 203,000 and a total daily readership in 1997 of 696,000 (Singapore Press Holdings 1999). These figures tower over the circulation of the publications servicing Singapore's minority ethnic groups. Nevertheless, between 1988 and 1999, daily Malay-language newspaper circulation grew from 42,458 to 59,690 and Tamil-language newspaper circulation rose from 5,635 to 9,833 (Singapore Department of Statistics 1999). Significantly, the advent of the Asian crisis has not stymied the growth of the local press. 
owner of all daily newspapers published in Singapore. SPH has used its massive capital base to ensure the highest technological standards of production and the commercial prospects of the group remain extremely bright.

While journalists working for the SPH group are well paid and have excellent infrastructure, they operate within a political context that conditions reporting and editorial orientation. This is most conspicuous in the lengthy and uncritical reproduction of government policy and ideological statements. Equally, the government's critics or detractors are often lampooned, ignored, or alternately, subjected to a relentless scrutiny of the sort those actually wielding power in Singapore are spared. In recent times there has been some increased space for non-establishment (but not opposition) figures to express criticisms of government policy through the forum pages of local newspapers. In the main, though, this concerns details of policy rather than any fundamental challenge to the PAP agenda or philosophy. By contrast, local press coverage of regional and international affairs is of a high standard. Even local business reporting is, within limits, of a reasonable standard-invariably more probing in its exposure and scrutiny of private organisations not under the considerable umbrella of government-linked companies.

Charges against Singapore's government-controlled press of political interference are common from neighbours, especially Malaysia. Throughout 1998 there was a string of complaints from Kuala Lumpur about negative reporting from Singapore's domestic media, including reports on the new international airport, tourism and the economy. Similar accusations are made from Singapore about reporting in Malaysia's government-controlled media.

One of the latest episodes concerns an editorial in the 18 June 1999 edition of Singapore's The Business Times. Among other things, in an analysis of issues surrounding a looming Malaysian election, the editorial lamented the possibility that Malaysian Prime Minister Mahathir would 'end up hogging the stage for longer than he should'. Singapore Prime Minister Goh Chok Tong's Press Secretary, Ong Keng Yong (1999), subsequently wrote to The Business Times describing the editorial as 'rash, unwise and inappropriate'. Essentially, the problem is not so much one of poor reporting. Rather, it is in frank and critical analysis of the region where local journalism is generally at its best. However, given that both 
governments understand the degrees of control each exert over local media, critical reports are invariably interpreted as having an imprimatur. At times, these conflicts can also be a useful way of shoring up nationalism and diverting attention from domestic issues.

\section{The international press bites its tongue}

The Singapore government was irritated by critical international press reporting in the 1960s and 1970s, but it did not seriously dedicate itself to combating it until the mid 1980s. With the domestic press now well under control, and against a background of a general election in 1984 in which the government vote slipped 13 per cent, authorities embarked on a clever and effective strategy to curb critical coverage of local affairs. The essence of this strategy has been to exploit the commercial instincts of international media organisations. Despite Singapore's size, its educated and affluent population represents a prize market for English-language publications in Asia-at least as much for its advertising dollar as its circulation sales. Costly legal cases have combined with measures to restrict access to this lucrative market to enforce a high degree of self-censorship among even the most reputable international media organisations operating in Singapore.

Under amendments to the NPPA in 1986, the Minister of Communications (now Information) can restrict the local circulation of newspapers published outside Singapore considered 'engaging in the domestic politics of Singapore'. Conveniently vague, the meaning of this phrase is a matter of the Minister's discretion. This of course leaves editors guessing where the line of tolerance might be drawn. The Act was further amended in 1988 to allow the reproduction and sale of restricted, or 'gazetted' publications in Singapore, on the proviso that advertisements are deleted. On this basis, the Singapore government rejects claims that it is obstructing critical comment. Instead, it contends, it is merely preventing newspapers and magazines from commercially profiting by 'engaging in the domestic politics of Singapore'. Additional amendments in 1990 introduced an annual permit system for 'foreign publications', involving a substantial bond that could be drawn on to cover any legal liabilities incurred in the local courts as a result of an offending story. Each publication was then required to appoint an agent in Singapore to ensure 
legal action encompassed the publisher as well as other parties, such as the author and distributor.

During the mid-to-late 1980s, TIME, Far Eastern Economic Review, The Economist, Asian Wall Street Journal and Asiaweek all incurred substantial circulation cuts-often amounting to de facto bans. With the exception of the case involving the Far Eastern Economic Review, a central theme to the disputes was the Singapore government's assertion of the right for its replies to articles to be published in 'offending' publications. At that time, Fred Zimmerman, of the Asian Wall Street Journal, insisted

[i] tis the fundamental condition of a free press that newspapers should be free to decide what they will print without fear or favour from any external source, and that it is the judgement of the editor and not the dictates of any government which should determine what appears in the newspaper (quoted in Dow Jones \& Co. 1990).

In conjunction with circulation cuts, various international journalists were expelled or had their visa applications denied. A string of legal actions were also exchanged between the government and publishers, including an unsuccessful attempt by Dow Jones to challenge circulation restrictions imposed on the Asian Wall Street Journal.

Despite the initial protests by members of the international press, by the early 1990s they had resigned themselves to the special conditions associated with reporting on Singapore. Government responses were being printed in full and, under new Vice-President Karen House, Dow Jones withdrew an appeal against a court decision in favour of Lee Kuan Yew. The Singapore government reciprocated by gradually restoring circulation levels and in 1997 granted the Far Eastern Economic Review permission to again locate a correspondent in the city-state. Without doubt, exclusion from the strategic Singapore market inflicted economic pain on these publications. Commercially, it made little sense to be in Asia but not in Singapore.

An equally effective means of discouraging critical reporting is the pursuit of publications through defamation, libel and contempt of court cases. The International Herald Tribune has been the major casualty of this practice. The first suit was in reaction to an article written by Philip Bowring entitled 'The claims about Asian values don't bear scrutiny', published on 2 August 1994. Lawyers for Lee Kuan Yew and his son, Deputy Prime Minister Lee Hsien Loong, complained to the Tribune that 


\section{- irculation of Singapore's media}

For the full year of 1998, average weekly circulation for specialist regional publications of Asiaweek was 15,867, The Economist 11,482 and Far Eastern Economic Review 7,892, while TIME, which now produces an Asian edition, averaged 30,181 . The average daily copies sold by the Asian Wall Street Journal was 8,078 and for the International Herald Tribuine 6,348 (Hong Kong Audit Bureau of Circulations 1999; US Audit Bureau of Circulations 1999; UK Audit Bureau of Circulations 1999).

the piece inferred that nepotism was responsible for Lee junior's political rise. Although the Tribune published an apology which many observers believed unwarranted, this didn't appease the Lees. Instead, the newspaper finished up in court and ultimately had to pay $\$ \$ 950,000$ in total damages, with Prime Minister Goh Chok Tong joining in on the action.

Subsequently, in response to the 7 October 1994 edition of the Tribune carrying a piece by Christopher Lingle, an American academic at the National University of Singapore, Lee Kuan Yew embarked on further law suits. Lingle had observed in 'The smoke over parts of Asia obscures some profound concerns' that some authoritarian regimes in the region use 'a compliant judiciary to bankrupt opposition politicians'. Lee interpreted this as an oblique reference to Singapore and the Singapore government mounted contempt of court actions against Lingle, the Tribune and the newspaper's distributors. Lee himself took civil libel suits out against Lingle and the executives of the Tribune.

Significantly, there was no attempt by the Tribune to defend its actions on the grounds of fair comment. This was deplored by leading international jurist and human rights activist Michael Kirby (Merritt 1995). Yet again Singapore's courts showed little mercy on the Tribune for coming quietly. All defendants in the action by the government were found guilty of contempt of court by way of 'scandalising the Singapore judiciary' (Lague 1995). The fines and costs amounted to in excess of $S \$ 100,000$. Additionally, in Lee's separate action, damages of $\$ \$ 100,000$ were awarded. After the major showdowns between publishers and the Singapore government over how local affairs are reported, international 
newspapers and magazines have been able to restore circulation levelstheir lessons learned.

While circulation cuts and costly legal actions vividly demonstrate government preparedness to punish reporting it finds unacceptable, these measures are intended to foster self-censorship, and avoid more draconian measures. For the most part, this is how things work as editors cautiously interpret the nebulous concept of 'engaging in the domestic politics of Singapore'. Periodically, however, miscalculations occur, serving only to instil even greater caution thereafter. The Tribune cases centred on two of the most sensitive topics - the interests of the Lee family and the judiciary - where there is virtually no margin for critical reporting. The net effect of the punitive consequences of upsetting authorities has resulted in most major international press organisations routinely drawing on legal advice before publishing reports that even remotely contain critical or sensitive content.

Self-censorship in Singapore is also encouraged by less conspicuous means. Employment passes are renewed on an annual basis, with an official policy of two to three years maximum stay. This is, however, selectively waived-apparently as a reward to those journalists deemed to have shown due sensitivity. The Ministry of Information and the Arts (MITA) has an extensive infrastructure monitoring in great detail what is being reported by international journalists. Official and unofficial communications through letters and phone calls-either from MITA or the Prime Minister's office-quickly educate journalists of this. Even the tone of an article can be enough to precipitate a phone call. These calls are not always hostile, and indeed sometimes quite friendly. But they invariably impress upon journalists that their reports are the subject of intense scrutiny. Journalists are also acutely aware of the possibility that their telephone conversations are being tapped.

The impact of this working environment means international media organisations-in varying degrees-fail to employ the same standards of investigative and critical reporting as elsewhere. One of the clearest illustrations of the way the international media has 'acclimatised' itself to local conditions was the coverage in 1996 of the controversial discounts on purchases of luxury private condominiums received by Senior Minister Lee and his family from HPL Limited. Reports were almost uniformly 
descriptive, repeatedly making the point that nothing illegal had occurred. The critical question of political morality was almost totally ignoredsomething one journalist volunteered he would elsewhere make the central issue in such a case (Rodan 1998). Details of the extent of Lee family purchases of private condominiums were eventually revealed in 1998 in an obscure offshore publication entitled Singaporeans for Democracy, produced by an organisation of the same name (Singaporeans for Democracy 1998).

The paradox is that none of these obstacles to the free practice of journalism have prevented Singapore from becoming Southeast Asia's pre-eminent media centre. How do we explain this? The answer lies in the fact that reporting on Singapore at all, let alone specifically on potentially controversial social and political issues, represents a minuscule component of total international media activities from the city-state. The vast bulk of reporting is either about the region or involves business data and information that steers well clear of the government's concerns. Singapore's advanced infrastructure renders it a very attractive base for regional reporting and Singapore boasted a total of 203 accredited correspondents and camera crews representing 73 international media organisations by the end of 1998.

\section{Broadcasting: business is business}

Over 90 per cent of Singaporean households own radios. The average number of daily hours of collective radio transmission increased from 653 to 2,828 between 1988 and 1998 (Singapore Department of Statistics 1999). A total of 18 domestic radio stations are available through Radio Corporation of Singapore (RCS), NTUC Media Cooperative Limited, SAFRA Radio, the National Arts Council (NAC) and the commercially run Rediffusion (Singapore) Pte Ltd, all of which are wholly or partly government owned. The British Broadcasting Corporation (BBC) World Service is also available on a local radio frequency - the only foreign freeto-air and completely independent station in Singapore. Foreign programming, including German, French and Japanese, is available on an international radio station operated by RCS.

There are four terrestrial channels operated by the government-owned Television Corporation of Singapore (TCS) and Singapore Television 
Twelve Pte Ltd (STV12). In addition, Singaporeans have access to all three Malaysian free-to-air channels - the government-owned RTM1, RTM2 and TV3. Terrestrial television licenses increased from 554,133 in 1988 to 704,296 a decade later (Singapore Department of Statistics 1999). TCS captures in excess of 90 per cent of the population and has a weekly audience reach of 82 per cent (Foo and Kwok 1999).

In broadcasting, though, it is undoubtedly the dramatic developments in satellite and cable television throughout the 1990s that are most noteworthy. The Singapore government continues to ban satellite television for all but selective business and diplomatic uses domestically. However, beginning in 1993 it started promoting the city-state as a regional base for the penetration of satellite and cable television markets in the rest of the region. Thus far it has attracted some 20 private broadcasters, including such major international networks as CNBC Asia, Discovery Asia, ESPN Star Sports, Walt Disney Television, Sony Entertainment Television (SET), Home Box Office Asia and BBC Worldwide.

The minor exceptions the government makes for domestic access to satellite television are explained in terms of the commercial imperative of up-to-the-minute information. But the government is also dedicated to preserving what it refers to as 'cultural values' and is not prepared to leave this to market forces (George 1994). It is therefore putting in place a comprehensive cable system to meet domestic demand for international broadcasts. This way it retains the technical ability to screen out 'objectionable' material. Cable television in Singapore is run by a conglomerate called Singapore Cable Vision (SCV). This is comprised of the three state companies Singapore International Media (31 per cent) Singapore Technologies Ventures (24 per cent), Singapore Press Holdings (20 per cent), and the third largest cable operator in the United States, Continental Cablevision ( 25 per cent). Currently it offers 46 channels, but when the infrastructure is completed, SCV will be able to offer around 70 channels to all Singaporean households. Cablevision subscriptions have risen from 22,214 when the medium was introduced in 1993 to 144,000 by the end of 1998 (Singapore Department of Statistics 1999). CNN, CNBC and $\mathrm{BBC}$ World can be received through SCV'S single cable news network.

To date, self-censorship among international companies eager to secure a position in the Singapore market has avoided the need for authorities to exercise much direct control over the content of cable television companies. 
$\mathrm{CNN}$ has gone as far as to alerting SCV of potentially sensitive material, as it did before screening coverage of a report involving US teenager Michael Fay who was caned after being found guilty of vandalising cars in Singapore (Atkins 1995). More generally, cable service providers have offered material that is either apolitical, such as music or sport, or that is family oriented and reinforces the sort of conservative values championed in government rhetoric. These companies are demonstrating the pragmatic nature of business; that there are profits to be made from accommodating rather than challenging authoritarian leaders in Asia.

Nevertheless, in March 1999, TCS launched an 18 hour all-news freeto-air television channel-Channel News Asia (CNA). The express purpose of the new station, as explained by George Yeo, Minister for Communications and the Arts between November 1990 and June 1999, is to provide an 'Asian viewpoint' on current events. The advertisements preceding the station's launch proclaimed that CNA understands the region's sensitivities and complexities (Dolven and Granitsas 1999). The government views with alarm the enhanced stature and influence of foreign satellite and cable television, linked to dramatic coverage of the tumultuous events in the region associated with the Asian crisis. Yeo remarked in parliament on 12 May 1999, '[j]ust look at the way foreign channels have become part of the domestic politics in Malaysia and Indonesia. We should worry for ourselves' (Fernandez 1999).

The Singapore government was especially irritated by international media coverage of the civil disobedience campaign of oppositionist Chee Soon Juan. Chee, Secretary-General of the Singapore Democratic Party, was twice jailed in early 1999 for speaking in a public place without a permit and refusing to pay fines for the offence. Yeo could not conceal his annoyance that editors would take Chee's push for free speech so seriously: '[w] have witnessed many interviews on CNBC and BBC with some populist politicians in Singapore of late for frivolous causes' (Associated Press 1999). The Minister put international cable television stations operating in Singapore on notice that there would need to be less coverage of government critics by the time of the next election. Yeo added, '[d]uring election time, the rules of campaigning must apply to these foreign channels, as they apply to TCS and STV 12 . Otherwise, some candidates may be tempted to lobby channels or even buy airtime from them' 
(Fernandez 1999). Exactly what that might entail is not clear. The practice that has been adopted by government-controlled media is for broadcasting time for political parties to be allocated in proportion to the number of candidates they are running at an election. The concept of 'right of reply' would be technically difficult to impose on this medium (Political \& Economic Risk Consultancy 1999).

The promotion of cable television is one component of a broader government strategy to transform Singapore into a leading global information technology society. Through the Singapore One cable network, all 750,000 households on the island will be connected to a comprehensive computer network by the end of 2000. Households, businesses, schools, government departments, libraries and statutory authorities will be electronically inter-linked to facilitate commercial and other transactions, as well as interactive services and communication through the Internet. According to Yeo (1995), this infrastructure drive is necessary for Singapore to 'remain a junction for goods, services, people, information and ideas' in the 21st century. But as with other electronic media, the government's aggressive promotion of the Internet is fundamentally driven by commercial objectives and accompanied by a desire to maintain a high degree of content control.

With approximately 40 per cent of its population now having direct Internet access, Singapore has one of the world's highest rates of Internet use. The number of Internet users in Singapore doubled between 1996 and 1998 to more than 500,000, while the number of websites in the citystate jumped from 900 to over 4,000 in the same period (Foo and Kwok 1999). As elsewhere in the media industry, the government's indirect presence looms large. All of Singapore's three Internet Service Providers (ISPs)-Cyberway, Pacific Internet and Singnet-are either governmentowned or government-linked companies. In corporatist Singapore, this necessarily leads to speculation about the level of cooperation between ISPs and authorities in surveillance of the Internet.

The technical capacity for surveillance has been amply demonstrated. In 1994, a total of 80,000 files were searched for 'GIF' (Graphic Interchange Format), in what authorities explained as a swoop on pornography (Shenon 1995). Then in early 1999, the computers of almost half of Singapore's 400,000 Internet subscribers were scanned without 
subscribers' knowledge. This involved the Ministry of Home Affairs and Singtel, both of which claimed the purpose was to identify which subscribers' computers were virus-infected (Sesser 1999).

Internet usage is regulated via a licensing system and guidelines that include the requirement of ISPs to filter material via proxy servers. Political parties and religious organisations must be licensed and ISPs have to obstruct access to web pages identified as objectionable by the Singapore Broadcasting Authority (SBA). According to The Internet Code of Practice '[p]rohibited material is that material that is objectionable on the grounds of public interest, public morality, public order, public security, national harmony, or is otherwise prohibited by applicable Singapore laws'. Currently the SBA screens out 100 such sites. They are not publicly identified, but all are pornographic according to authorities.

When opposition political parties attempted to employ the Internet in the lead-up to the 1997 election, they were instructed by the SBA to remove biodata and posters of candidates from their web sites. They were deemed to have contravened the Parliamentary Elections Act, which predates the technology of the Internet, because the rules pursuant to the Act did not provide for campaigning on the Internet. Incidentally, amendments to the Films Act in 1998 also ban political advertising using films or videos. Authorities' attempts to limit the political impact of new electronic technologies also draws on the same libel and defamation laws that have intimidated other media. The PAP's ideological hegemony is another factor in the moderate political impact of the Internet in Singapore. Discussion groups operate within self-imposed and unconscious boundaries. The inclination to draw on alternative sources of analysis and information through the web is also conditioned by political motivation or lack thereof.

\section{Constraints range from the bland to the sophisticated}

Already the discussion has touched on various factors constraining the media in Singapore, including the various provisions of the Newspaper and Printing Presses Act, the use of defamation, libel and contempt of court suits, the Official Secrets Act and the Internal Security Act. Additional legislation that can be harnessed to restrict what is published are the Sedition Act and the Undesirable Publications Act. The former prohibits speeches and publications with 'seditious tendency', which includes 
arousing people's disaffection with the government and the judiciary and between races and classes. Under the latter Act, which covers books and magazines, such publications as Playboy, Penthouse and Cosmopolitan are banned in Singapore, but so too are some religious and political materials. In 1998, the Act was amended to include CD-ROMs, sound recordings, pictures, and computer-generated drawings.

An additional constraint on reporting in Singapore is the difficulty of getting information other than that which authorities are promoting. This problem involves state bureaucrats and the private sector, as well as politicians. However, the government sets the tone for this in two important respects: first, by its view on information as a matter for strategic control, and second, by its political resistance to citizenship claims about the right to information.

Official rhetoric about transparency reform is currently high in Singapore, as part of the government's ambitious attempt to promote the city-state as an international financial centre. Indeed, there have been some important improvements towards greater corporate disclosures. Local banks, for example, are now required to publicly declare the extent and nature of bad loans and previously undisclosed reserve assets. These changes are certainly helpful for business journalists as well as shareholders. Meanwhile, however, state control over a great deal of information is likely to be retained for both commercial and political reasons.

A few examples illustrate how strategic control restricts some basic data, with obvious implications for reporting. Singapore-Indonesia trade figures are not published. These data are sensitive politically because during Konfrontasi in 1963 there was supposed to be an embargo on trade between Malaysia (of which Singapore was a part at the time) and Indonesia. They are sensitive commercially because they could reveal a discrepancy with Indonesian records of what has been exported to Singapore and, by inference, demonstrate the extent of smuggling into the city-state. Information about the number and nationalities of permanent residents and guest workers in Singapore is also not freely available. This limits informed analysis of the domestic labour forcewhether in terms of supply questions or the social impact of imported labour. From the government's perspective, though, these are sensitive ethnic and racial issues to be managed through information control 
(Dolven 1999). The government may periodically release unpublished data on such issues, but this will be a matter of discretion.

One of the most significant information black holes concerns the operations of the government's investment arms, an issue over which Singapore earned the criticism of the IMF in March 1999 (IMF Public Information Notice No. 99/26). They are shielded from any detailed public record or scrutiny, despite the enormous scale and importance of the capital involved. The Government Investment Corporation (GIC) manages more than $\mathrm{S} \$ 100$ billion of taxpayers' money in overseas investments. Its sister firm Temasek Holdings presides over $\$ \$ 34$ billion, most of which is invested among the more than one thousand government-linked companies (GLCs). Singapore's legal and regulatory regimes exempt both from routine external reviews of operations. The GIC is especially secretive, exempted from any purview by the Auditor General or Accountant General and with no requirement to report to parliament. It reports only to its board, which is chaired by Lee Kuan Yew. Temasek Holdings reports selectively and only to the Finance Minister and a small parliamentary budget committee (Vennewald 1994).

GLCs listed with the Stock Exchange of Singapore (SES) do divulge investment details as required by regulations. However, little extra is volunteered. With few exceptions, GLCs are amongst the poorest performers in independent rankings of corporate transparency in Singapore (Teo 1999). They are also distinctly uncooperative with financial journalists and openly discriminatory towards the international media. The international media have also been excluded from press conferences by the SES and statutory boards, resulting in letters of protest from both the Foreign Correspondents' Association and individual media companies.

Another problem for journalists is that state bureaucrats tend to act as custodians of the ruling party's policies and interests. This often translates into political judgements in information management. The suppression of civil society since the mid 1960s has also freed bureaucrats from interest group pressure to reveal more detail than they wish about government activities. Singapore's outgoing President and former Second Deputy Prime Minister, Ong Teng Cheong, dramatically highlighted the absence of transparency within the public sector in a recent speech. The President's most important constitutional responsibility is to safeguard official reserves. Yet Ong revealed that in 1993, when he asked the Accountant- 
General what total reserves were, he was told the data had not been systematically collected and the value of assets was difficult to determine. His request for an inventory, he was told, would take ' 52 man years' to accommodate. He finally received a list of properties in 1997 (Ibrahim 1999). Obviously journalists without Ong's degree of authority face even greater difficulties in extracting information.

On one of the rare occasions that a journalist was able to penetrate state control over sensitive data, the repercussions were serious. In 1992, the Business Times reported seemingly innocent official 'flash estimates' of economic growth ahead of official release. Two years later an economic director from the Monetary Authority of Singapore, the editor and the journalist from the Business Times, and two economists from a stockbroking firm were found guilty of breaching the Official Secrets Act and fined.

Not surprisingly, nothing approximating a Freedom of Information Act exists in Singapore, nor is it being contemplated. On the contrary, there are signs that the government is drawing a clear distinction between improved corporate transparency and broader dimensions of open governance. The Prime Minister's private secretary, Tan Tee How, dismissed the establishment recently of an Open Singapore Centre by two opposition politicians. According to Tan, there is no need for such a centre because Singapore is widely recognised as an open society, practising transparency and democratic accountability (The Straits Times Interactive 1999b). It was an almost comic irony that the tea party launch of the Open Singapore Society on 12 June 1999 appeared to attract official surveillance (Gomez 1999). In Singapore, it seems, advocacy of political transparency arouses suspicion of subversion.

Finally, journalists face the problem of the deep reluctance of those with dissenting views to put their opinions on the record. The Singapore government has an extensive range of commercial interests and therefore dispenses a great many contracts. It also has a record of legal recourse against critics. There is a widespread perception that there is nothing to gain and everything to lose from being quoted.

None of the above observations mean that there is not a lot of official and publicly available information in Singapore. On the contrary, there is an abundance of it-much very helpful to journalists. But it is also predominantly information that either reinforces state economic, social and political agendas or cuts the costs of business transactions. In other 
words, it is information functional to state strategic objectives. Journalists are courted with this through extensive and well-resourced public relations machinery.

\section{Assessment: a love-hate relationship}

In Singapore, the influence of the government over the media is considerable-both through a string of regulations and also more indirectly through the dominance of government-linked companies in the industry. This influence over the local media translates into a marked reporting bias in favour of the ruling party. Scrutiny of the PAP's exercise of power is therefore minimal and debate over alternative political ideas is systematically restricted. Not surprisingly, in Freedom House's 1999 worldwide assessment of press freedom, Singapore was ranked 'not free'. In terms of the safety of journalists, the city-state was awarded the highest possible ranking, but in the laws and regulations governing content and the extent of political pressures imposed on reporting, it fared poorly. Under such a regime, the media are limited in the capacity to assist informed public debate and the development of a genuine civil societya fundamental precondition for liberal democracy-is not possible.

However, from the perspective of the Singapore government, these observations are predictable and grounded in a false assumption. The PAP doesn't share its critics' views on the virtues of liberal democracy. On the contrary, it wants to avoid the sort of competitive politics championed by its critics. In its place, it remains committed to the consolidation of a political system that embodies a high degree of statesponsored consensus. Clearly, the media have a critical ideological role to play in producing that consensus. Securing this, however, is an ongoing exercise that must take effective account of the dynamics of contemporary Singapore and the international context within which Singapore operates. Technological developments and the information requirements of an increasingly sophisticated market system are among the more obvious challenges to the city-state's control-minded authorities.

Whatever the challenges, the capacity of the Singapore government to reconcile high levels of media control with market development is impressive. In spite of the absence of media freedom, Singapore has become both a regional media centre and Southeast Asia's most advanced 
economy. The economy has also withstood the Asian crisis far more effectively than other economies in the region with freer flows of information and critical analysis.

The likely trajectory is for the Singapore government to continue to maintain high levels of media control, and to engage in periodic clashes with the international media for not playing by the same rules as their local counterparts. Yet for all the friction that characterises relations with the international media, the government-and Lee Kuan Yew in particular-has used them very effectively to both promote the local economy and to project views onto the global political stage. The local media also selectively harness their reports in the service of domestic political agendas. The international media and the Singapore government seem to need each other, but for a while yet it may continue as a lovehate relationship.

\section{Media websites}

AsiaOne-Lianhe ZaoBao, www.asia1.com.sg/zaobao/

Asia Business News, www.abn-online.com/abn/

Berita Harian, http://cyberita.asia1.com.sg/

Business Times, http://business-times.asia1.com.sg/

Cy Berita, http://cyberita.asia1.com.sg/

Lianhe Zaobao, www.asial.com.sg/zaobao/

NTUC News, http://web1.asia1.com.sg/ntuc/news/

Singapore Business Times, http://business-times.asia1.com.sg/

Straits Times Interactive, http://straitstimes.asia1.com.sg/ 